\title{
Farmers' Perceptions about Adaptation Practices to Climate Change and Barriers to Adaptation: A Micro-Level Study in Ghana
}

\section{Francis Ndamani ${ }^{1, *}$ and Tsunemi Watanabe ${ }^{2}$}

1 Graduate School of Engineering, Kochi University of Technology, 2-22 Eikokuji, Kochi City, Kochi 780-8515, Japan

2 School of Economics and Management, Kochi University of Technology, 2-22 Eikokuji, Kochi City, Kochi 780-8515, Japan; E-Mail: watanabe.tsunemi@kochi-tech.ac.jp

* Author to whom correspondence should be addressed; E-Mail: fndamani@gmail.com; Tel. +81-80-3168-7090.

Academic Editor: Yingkui Li

Received: 14 July 2015 / Accepted: 18 August 2015 / Published: 25 August 2015

\begin{abstract}
This study analyzed the farmer-perceived importance of adaptation practices to climate change and examined the barriers that impede adaptation. Perceptions about causes and effects of long-term changes in climatic variables were also investigated. A total of 100 farmer-households were randomly selected from four communities in the Lawra district of Ghana. Data was collected using semi-structured questionnaires and focus group discussions (FGDs). The results showed that $87 \%$ of respondents perceived a decrease in rainfall amount, while $82 \%$ perceived an increase in temperature over the past 10 years. The study revealed that adaptation was largely in response to dry spells and droughts (93.2\%) rather than floods. About $67 \%$ of respondents have adjusted their farming activities in response to climate change. Empirical results of the weighted average index analysis showed that farmers ranked improved crop varieties and irrigation as the most important adaptation measures. It also revealed that farmers lacked the capacity to implement the highly ranked adaptation practices. The problem confrontation index analysis showed that unpredictable weather, high cost of farm inputs, limited access to weather information, and lack of water resources were the most critical barriers to adaptation. This analysis of adaptation practices and constraints at farmer level will help facilitate government policy formulation and implementation.
\end{abstract}


Keywords: climatic effects; agricultural production; farmer perceptions; adaptation constraints; Lawra district

\section{Introduction}

Climate change prediction models have indicated that the Sudan and Guinea Savanna zones of Ghana will continue to experience increasing temperature and decreasing precipitation trends [1]. This confirms previous findings that between 2030 and 2039 the rainy season might start in June or even later in Northern Ghana [2]. It is also projected that the standard deviation for the onset of the rainy season will increase [3], which suggests that not only will it shift but also it will become even more "erratic" [4]. The implications are that Northern Ghana would witness more extreme weather conditions such as droughts, dry spells, and floods. This situation will eventually affect agriculture, the environment, and human livelihoods. In particular, it is anticipated that adverse impacts on the agricultural sector will exacerbate the incidence of rural poverty [5]. Adaptation practices are therefore needed to help agrarian communities better face extreme weather conditions associated with climate variations [6].

Adaptations are adjustments or interventions that take place to manage the losses or take advantage of the opportunities presented by a changing climate. Adaptive capacity has been defined as the ability of a system to adjust to climate change (including climate variability and extremes), to moderate potential damages, to take advantage of opportunities, or to cope with the consequences [7]. Adaptation practices are therefore pre-emptive in nature. They are designed to mitigate potential adverse effects and take advantage of the potential benefits of an envisaged change in climatic variables.

Several studies in Ghana have reported adaptation practices in agriculture, including crop diversification, change of planting date, hybrid varieties, and soil moisture conservation techniques $[8,9]$ In Uganda, income diversification, digging of drainage channels, and the use of drought-tolerant varieties have been reported [10]. In addition, mixed farming, mixed cropping, tree planting, use of different crop varieties, changing planting and harvesting dates, increased use of irrigation, increased use of water and soil conservation techniques, and diversifying from farm to non-farm activities have also been reported in Nigeria and in South Africa [11,12].

Globally, many studies have been used to understand farmers' perceptions about climate change and its associated effects on agriculture. Although perceptions are not necessarily consistent with reality, they must be considered to address socioeconomic challenges [13]. Perception has been defined as the process by which organisms interpret and organize sensation to produce a meaningful experience of the world [14]; and that a person's perceptions are based on experiences with natural and other environmental factors that vary in the extent to which such perceptions are enabled [15]. Previous studies have shown that the way in which people experience climate shocks varies across different social groups, geographic locations, and seasons of the year, with men, women, and children all experiencing different levels of hardship and opportunity in the face of climate change [16].

Discussions of adaptation practices and barriers to adoption need to be informed by empirical data from farmers. Adaptation practices in agriculture are generally location-specific [17]; hence, it is crucial to understand farmers' perceptions about the risks they face. To ensure farmers' readiness for extreme 
weather events and collaboratively learn about the evolution of weather patterns, efforts to focus on farmers and their current activities, knowledge, and perceptions are essential [18,19]. Farmers' willingness to accept and use prescribed measures could be enhanced if their perceptions and understanding are considered in designing such measures. By contrast, current models used in predictions of climate change and adaptation practices are at a global scale and need to be downscaled to accommodate realities at the community level [9].

In the Lawra district of Ghana, agriculture production is the dominant source of food and household incomes for the vast majority of rural households. Agriculture production is largely rain-fed. Farmers' dependence on an annual mono-modal rainfall pattern coupled with farm resource constraints make agriculture very vulnerable to the impacts of climate change. Results of previous studies have revealed a negative correlation between seasonal rainfall and volume of staple crops (i.e., sorghum, millet, and groundnut) produced annually in the Lawra district over the past 20 years [20]. This study explored farmers' perceptions regarding long-term changes in climatic variables and the associated effects on farming. It also identified and prioritized adaptation practices based on farmers' perceived importance. Constraints on the use of adaptation measures were also identified and ranked. This study will help government policy decisions about suitable adaptation practices that are applicable and most preferred by farmers. It will also ensure that critical barriers to adoption are effectively addressed.

\section{Materials and Methods}

\subsection{Survey Design and Study Area}

This study is based on a cross-sectional survey data from farming households across four communities (i.e., Brifo-chaa, Methuo, Kalsagri, and Oribili) in the Lawra district of Ghana, located at longitude $10^{\circ} 30^{\prime} \mathrm{N}$ and latitude $2^{\circ} 35^{\prime} \mathrm{W}$. The district lies within the Guinea Savanna Zone, with mean annual rainfall ranging from 900 to $1200 \mathrm{~mm}$. It has two seasons: the dry season (November-April) and the rainy season (May-October). The vegetation is guinea savanna grassland characterized by shrubs and medium-sized trees, such as shea-tree, dawadawa, baobab, and acacia. The soils are mainly laterite soils developed from birimian and granite rocks. These soils are shallow sandy loam with medium coarse quartz stones. Recurrent droughts, dry spells, and floods tend to have adverse effects on crop production. The major crops produced include maize, sorghum, millet, and groundnut. Crop production activities take place within the rainy season. Eighty percent of the district's total population of 100,929 is engaged in rain-fed subsistence agriculture [21] The district was chosen because, based on historical data from the Ghana Meteorological Agency, it is more prone to extreme weather conditions. According to the [21], Lawra is the poorest district in the upper west region of Ghana.

A total of 100 farming households were randomly selected for the interviews. Semi-structured questionnaires were used to investigate farmers' perceived changes in temperature and rainfall, causes and effects of climate change, and adaptation practices being used by farmers. Four focus group discussions (FGDs) were conducted to double check the survey data. The household survey and FGDs were conducted between February and November 2014 with the assistance of three regional and four district agricultural officers. The selection of communities was based on the accessibility and knowledge of agricultural officers. 


\subsection{Statistical Analysis}

Data were entered and analyzed using statistical package for the social sciences (SPSS). Frequencies, percentages, and means are the basic descriptive statistical tools used to represent farmers' perceptions about long-term changes in climatic variables and the associated causes (Table 1). In determining farmers' perceived importance of adaptation practices, respondents were requested to score selected practices based on a $0-3$ scale, where 0 is the least important practice and 3 is the most important practice. The adaptation practices were then ranked using the weighted average index (WAI):

$$
\mathrm{WAI}=\frac{\sum F i W i}{\sum F i}
$$

where $F=$ frequency of response; $W=$ weight of each score; and $i=$ score $(3=$ highly important; $2=$ moderately important; $1=$ less important; $0=$ not important).

Table 1. Description of data variables.

\begin{tabular}{ccc}
\hline Variables & Mean & Standard Deviation \\
\hline Age (15-34 years = 1; 35-54 years = 2; above 55 years = 3) & 2.26 & 0.73 \\
Education level (literate = 1; illiterate =0) & 0.21 & 0.41 \\
Farm size (continuous) & 4.95 & 1.70 \\
Household size (continuous) & 8.20 & 5.12 \\
Family labor (continuous) & 4.65 & 3.04 \\
Annual farm income-Ghana cedi (continuous) & 949.42 & 1909.55 \\
Annual off-farm income-Ghana cedi (continuous) & 797.20 & 2459.92 \\
Farmer's adaptation (adapted = 1; not adapted =0) & 0.67 & 0.47 \\
\hline
\end{tabular}

Previous studies have also applied the weighted average index (WAI) to assess farmers' perceived important adaptation strategies in Bangladesh and barriers of adaptation to climate change in Nepal [22,23].

To identify the critical constraints that hinder farmers from using adaptation practices, a ranking was conducted using the Problem Confrontation Index (PCI). Respondents were asked to grade their perceived barriers based on a 0-3 Likert scale (i.e., ranging from "not a problem" to "highly problematic"). The PCI value was estimated using the formula below:

$$
\mathrm{PCI}=P_{n} \times 0+P_{1} \times 1+P_{m} \times 2+P_{h} \times 3
$$

where:

PCI $=$ Problem Confrontation Index;

$P_{n}=$ Number of respondents who graded the constraint as no problem;

$P_{l}=$ Number of respondents who graded the constraint as low;

$P_{m}=$ Number of respondents who graded the constraint as moderate;

$P_{h}=$ Number of respondents who graded the constraint as high. 


\section{Results}

\subsection{Farmers' Perceptions of Long-Term Temperature and Rainfall Changes}

The majority of farmers $(82 \%)$ perceived an increase in temperature over the past 10 years (Figure 1). About $9 \%$ of respondents perceived no change, $6 \%$ perceived a decreasing change in temperature, and $3 \%$ did not know if there was a long-term change in temperature (Figure 1). Similar results were obtained from the focus group discussion. Generally, farmers believe that the increasing temperature trend was associated with the changes in precipitation. A total of $87 \%$ of respondents claimed that the rainfall amount has been decreasing over the past 10 years, $6 \%$ perceived no change in precipitation, and $7 \%$ gave other responses. Results obtained from FGDs proved that this perception was unanimous among farmers.

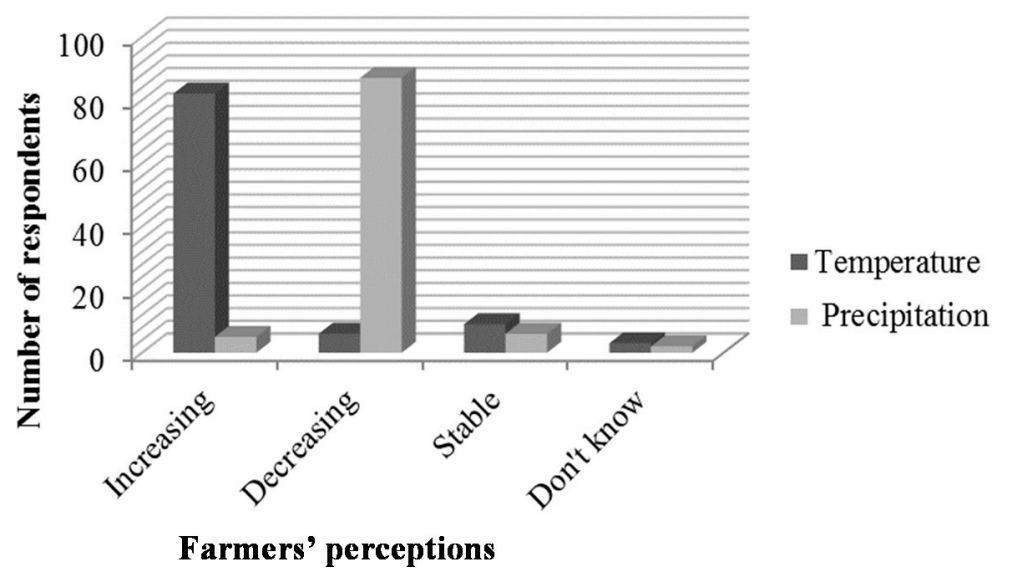

Figure 1. Farmers' perceptions of long-term changes in temperature and precipitation in the Lawra district of Ghana.

To verify farmers' perceptions regarding the precipitation trend, available historical annual rainfall data from 1980 to 2012 were obtained from the upper west regional weather station of the Ghana Meteorological Agency. The results indicated high variability rather than a clear decreasing trend in precipitation (Figure 2).

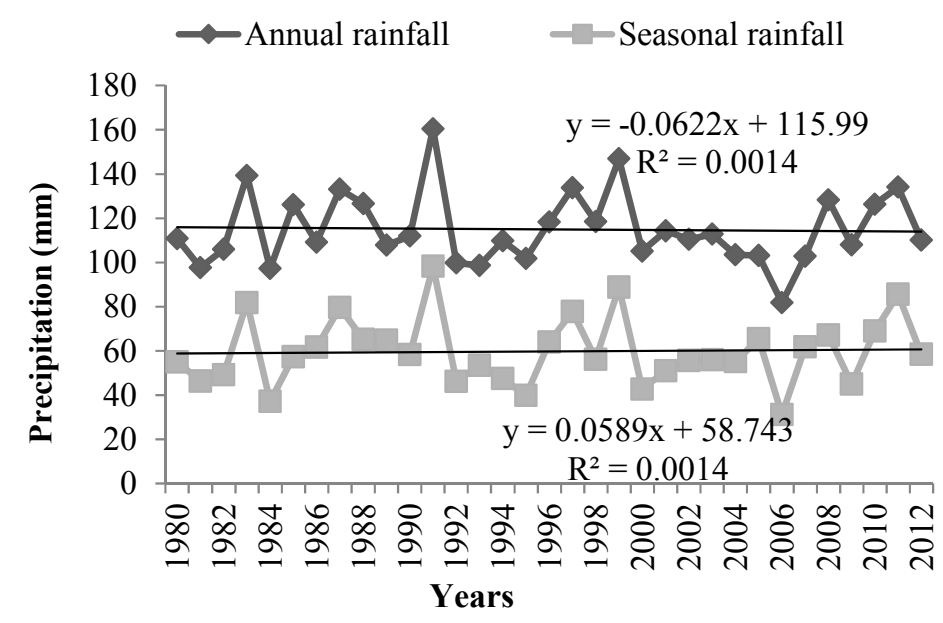

Figure 2. Annual and seasonal rainfall $(\mathrm{mm})$ in the Lawra district of Ghana (The rainfall data was collected directly from the office of the meteorological agency: Ghana Meteorological Agency, 2014). 
In addition, the results of discussions with the district agricultural officers confirmed the results of statistical analysis on the long-term trend in precipitation. Thus, the difference between farmers' perceptions and statistical results is due to the fact that farmers' responses are based solely on recall. The high illiteracy rate among farmers in Lawra district hinders their ability to keep formal records, and so accurately recalling long-term trends of rainfall could be difficult.

\subsection{Farmers' Perceived Causes of Climatic Variability on Agriculture}

Most farmers attributed climate change to human-related causes such as bush fires (51\%) and deforestation (14\%). While deforestation is largely perceived as being for the purposes of fuel wood, charcoal, and farm expansion, bush fires are believed to be caused by the 'negligence' of hunters and cigarette smokers. About $9.3 \%$ of respondents also claimed that traditional gods and ancestral spirits were responsible for the perceived changes in rainfall and temperature trends. During the FGDs, farmers indicated that the gods/ancestors were angry because many taboos have been broken by people (e.g., destroying sacred groves or woods, catching of sacred fish, etc.). Additionally, 23.3\% of respondents claimed that climate change is caused by many factors, while $2.4 \%$ could not give any cause (Table 2 ).

Table 2. Farmers' perceptions about the causes of climate change in the Lawra district of Ghana (Number of respondents $=100)$.

\begin{tabular}{cc}
\hline Cause Variable & Percentage of Respondents \\
\hline Deforestation & 14.0 \\
Bush fires & 51.0 \\
More than one cause & 23.3 \\
Gods/ancestral spirits & 9.3 \\
Do not know & 2.4 \\
Total & 100 \\
\hline
\end{tabular}

\subsection{Farmers' Adaptation to Climate Change}

The results revealed that farmers' adaptations are largely in response to dry spells (73\%). However, $20 \%$ and $7 \%$ of respondents indicated that they used adaptation options in response to droughts and floods, respectively. Although an overwhelming majority of farmers recognized climate change, $33 \%$ of respondents still do not use any adaptation practices (Table 3).

Table 3. Proportion of farmers by adaptation classification and reasons for adaptation in the Lawra district of Ghana (Number of respondents $=100)$.

\begin{tabular}{cc}
\hline Variable & Percentage of Respondents \\
\hline a. Adaptation classification & 67 \\
Adapted & 33 \\
Not adapted & \\
\hline b. Reasons for adaptation & 7 \\
Reduce effects of flood & 20 \\
Reduce effects of drought & 73 \\
Reduce effects of dry spell & \\
\hline
\end{tabular}




\subsection{Farmer-Perceived Importance of Adaptation Practices}

The ranking of adaptation practices based on farmers' perceived importance is presented in Table 4 . Among the seven adaptation practices, improved crop varieties and irrigation practice ranked first and second with a WAI of 2.15 and 2.09, respectively. The increasing incidence of drought and dry spells makes drought-tolerant crop varieties and irrigation preferable to farmers. On the other hand, income-generating activities and agroforestry practice were ranked the least important with a WAI of 0.77 and 0.74 , respectively. Results of FGDs showed that farmers considered trading and agroforestry as capital-intensive activities. Crop diversification, farm diversification, and change of planting date were ranked as moderately important.

Table 4. Farmers' ranking of adaptation practices in the Lawra district of Ghana (Number of respondents $=100$ ).

\begin{tabular}{cccccccc}
\hline & \multicolumn{2}{c}{ Frequency by Each Level of Importance } & & \\
\cline { 2 - 5 } Adaptation Practice & $\begin{array}{c}\text { Highly } \\
\text { Important }\end{array}$ & $\begin{array}{c}\text { Moderately } \\
\text { Important }\end{array}$ & $\begin{array}{c}\text { Less } \\
\text { Important }\end{array}$ & $\begin{array}{c}\text { Not } \\
\text { Important }\end{array}$ & WAI & Rank \\
\hline Improved crop varieties & 35 & 48 & 14 & 3 & 2.15 & 1 \\
Irrigation & 30 & 51 & 17 & 8 & 2.09 & 2 \\
Crop diversification & 14 & 76 & 8 & 2 & 2.02 & 3 \\
Farm diversification & 7 & 67 & 23 & 3 & 1.78 & 4 \\
Change of planting date & 10 & 44 & 26 & 20 & 1.44 & 5 \\
Income generating activities & 3 & 20 & 28 & 49 & 0.77 & 6 \\
Agroforestry practice & 0 & 9 & 56 & 35 & 0.74 & 7 \\
\hline
\end{tabular}

The results of actual adaptation measures being implemented by farmers are presented in Figure 3 . The majority of farmers use crop diversification practices such as mixed cropping (41\%) and crop rotation (10\%). About $12 \%$ of the respondents use improved crop varieties (i.e., drought-tolerant and early maturing varieties), while $23 \%$ adopted change of planting date. Other identified adaptation practices being implemented are off-farm jobs $(6 \%)$, composting and mulching $(3 \%)$, reduction in farm size (3\%), and dry season gardening $(2 \%)$.

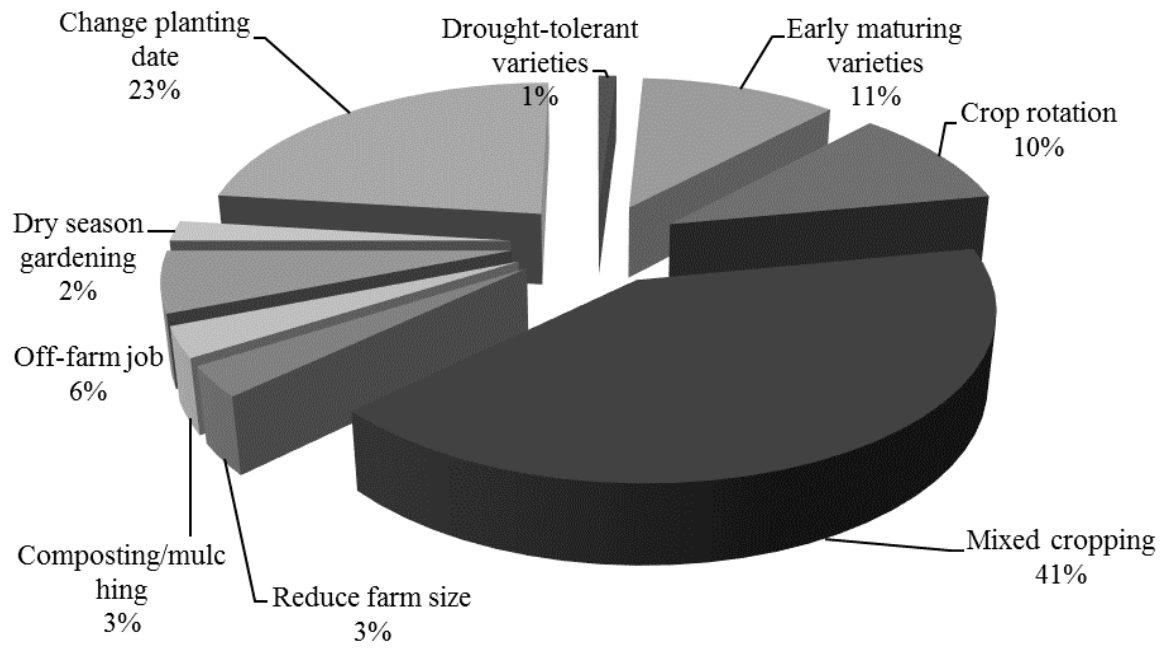

Figure 3. Actual adaptations being used by farmers in the Lawra district of Ghana. 


\subsection{Perceived Constraints to Adaptation to Climate Change}

Results on barriers to use of adaptation practices are presented in Table 5. With a PCI value of 215, unpredictable weather was ranked the most critical impediment to use of adaptation options. High cost of farm inputs, lack of access to timely weather information, and lack of water resources were ranked the second, third, and fourth most pressing problems, respectively. The FGDs showed that farmers' main source of weather information was colleagues who visited peri-urban towns during market days. The focus group discussions also confirmed that farmers considered lack of credit facilities, agricultural subsidies, and poor soil fertility as moderate constraints, while lack of access to agricultural extension officers, agricultural markets, farm labor, and farm size are the lowest constraints.

Table 5. Problems affecting implementation of adaptation practices in the Lawra district of Ghana (Number of respondents $=100$ ).

\begin{tabular}{|c|c|c|c|c|c|c|}
\hline \multirow{2}{*}{ Constraints to Adoption } & \multicolumn{4}{|c|}{ Degree of Constraint } & \multirow{2}{*}{ PCI } & \multirow{2}{*}{ Rank } \\
\hline & High & Moderate & Low & No Problem & & \\
\hline Unpredictable weather & 35 & 48 & 14 & 3 & 215 & 1 \\
\hline High cost of farm inputs & 14 & 76 & 8 & 2 & 202 & 2 \\
\hline Lack of access to timely weather information & 7 & 67 & 23 & 3 & 178 & 3 \\
\hline Lack of access to water resources (e.g., dams) & 10 & 44 & 26 & 20 & 144 & 4 \\
\hline Lack of access to credit facilities & 2 & 32 & 11 & 55 & 81 & 5 \\
\hline Lack of access to agricultural subsidies & 3 & 20 & 28 & 49 & 77 & 6 \\
\hline Poor soil fertility & 0 & 9 & 56 & 35 & 74 & 7 \\
\hline Limited access to agricultural extension officers & 3 & 19 & 7 & 71 & 54 & 8 \\
\hline Limited access to agricultural markets & 0 & 0 & 24 & 76 & 24 & 9 \\
\hline Inadequate farm labor & 0 & 1 & 19 & 80 & 21 & 10 \\
\hline Limited farm size & 0 & 0 & 13 & 87 & 13 & 11 \\
\hline
\end{tabular}

\section{Discussion}

Generally, farmers are aware of climate change, since more than $80 \%$ of the surveyed respondents have perceived long-term changes in temperature and precipitation trends. In Sub-Saharan Africa, similar findings have been reported in the Sekyedumase and Wa West districts of Ghana $[8,13]$, Uganda [10], and Senegal [24]. Other studies have also shown that, in the last 100 years, there has been an average global temperature increase of $0.74{ }^{\circ} \mathrm{C}[25]$.

Climate change model predictions for the Guinea Savannah Zone of Ghana revealed that the increasing temperature and decreasing precipitation trends will continue [1]. This implies that agricultural stakeholders should identify relevant and applicable adaptation practices to mitigate the effects of the impending change in climatic variables.

The study showed that farmers' perceptions about the causes of climate change are mostly centered on human factors (i.e., deforestation and bushfires) and gods/ancestral curses. Similar findings have been reported in the Wa West district of Ghana [13] and in Northern Nigeria [5].

This study showed that some farmers are already adjusting their farming activities in response to droughts, dry spells, and floods. The FGDs revealed that increased access to agricultural extension officers has impacted positively $(67 \%)$ on farmers' implementation of adaptation options. Similar 
findings were reported in Bangladesh, where more than $75 \%$ of respondents were using adaptation practices [23]. However, a previous study conducted in the Sekyedumase district of Ghana showed that less than $44 \%$ of farmers use adaptation measures due to lack of funds [8].

This study also revealed that farmer-perceived important adaptation practices were different from the actual practices being implemented. Although farmers ranked improved crop varieties (e.g., drought-tolerant and early maturing crops) and irrigation as the most important adaptation strategies, only $14 \%$ actually implemented measures in these categories. The majority of respondents (51\%) used crop diversification activities (i.e., mixed cropping and crop rotation). Similar findings were reported in Northern Nigeria [5]. Feedback from the group discussions showed that most farmers did not have access to improved crop varieties; hence, they could not implement their most preferred measure. Results of the group discussion showed that farmers are generally aware of the annual recurrent dry spells and droughts. Also, although they view irrigation as the most important solution to these extreme climatic events, they failed to rank it as such. This is because, according to farmers, water resources such as dams and dugouts are very limited in the district. Field observation showed that most of the available water bodies for irrigation are broken down.

Also, in this study, unpredictable weather, high farm input cost, and limited access to timely weather information and water resources were identified as the most critical barriers to adoption. This is likely the case, because in Ghana, the main sources of weather information are television and radio broadcasts. The majority of farmers surveyed did not have electronic gadgets and hence could not readily access weather information. Also, the FGDs revealed that farmers in the Lawra district operate under limited resources due to limited agricultural credit and subsidies. Field observations revealed that the limited number of irrigation facilities (i.e., dams and dugouts) were either broken down or dried out. Similar barriers to adoption have been reported in South Africa [12] and Nigeria [26].

\section{Conclusions}

With properly tailored policies, smallholder farmers can adjust to climate change and improve their crop production. To do this, climate change policies need to factor in farmers' understanding of the risks they face and potential adaptations to climate change. In this regard, interventions of the Ghanaian government should focus on the development of improved crop varieties and irrigation facilities. More specifically, the development of drought-tolerant crop varieties and the construction of dams and dugouts need to be prioritized in the list of climate change adaptation practices in the Lawra district. Also, there is a need for stakeholders to adhere to proper management and maintenance of existing irrigation facilities.

The perception that climate change is also caused by traditional gods and ancestral curses implies that scientists and development experts should consider the cultural and traditional beliefs of farmers when designing adaptation practices. As such, a bottom-up approach must be used to ensure that farmers' beliefs and understanding are a crucial part of the design and dissemination of adaptation practices.

Farmers' access to timely weather information also needs to be prioritized to help farmers in their production decision-making processes (e.g., selection of adaptation options). The Ghana Meteorological Agency and agricultural staff need to be properly trained and resourced to collect, collate, and disseminate accurate weather information timely and widely. Also, the government should boost the capacity of scientists and agricultural staff to develop and promote appropriate and effective technologies to 
help farmers adapt to climate change. In addition, the prevailing high cost of farm inputs and lack of credit facilities and subsidies require the government to ensure that agricultural loans with flexible terms are made available to farmers to boost their capacity to adapt to the changing climate.

Finally, further research is recommended to assess the feasibility of farm-level adaptation practices to climate change. This will help governments, researchers, non-governmental organizations (NGOs), and farmers to develop and implement adaptation measures that are sustainable, resilient, and reliable.

\section{Acknowledgments}

This study was funded by the Kochi University of Technology, Kochi, Japan. The authors gratefully acknowledge the valuable support of the farmers, agricultural officers, and local government staff of the Lawra district of Ghana.

\section{Author Contributions}

Francis Ndamani conceived the idea of the study, carried out data collection and data analysis. Tsunemi Watanabe supervised data collection and data analysis. Both authors drafted the manuscript, read and approved the final manuscript.

\section{Conflicts of Interest}

The authors declare no conflict of interest.

\section{References}

1. USAID. Ghana Climate Change Vulnerability and Adaptation Assessment. Available online: http://www.encapafrica.org/documents/biofor/Climate\%20Change\%20Assessment_Ghana_\%20F INAL.pdf (accessed on 23 April 2015).

2. Jung, G.; Kunstmann, H. High-resolution regional climate modelling for the Volta Basin of West Africa. J. Geophys. Res. 2007, 112, doi:10.1029/2006JD007951.

3. Laux, P.; Kunstmann, H.; Bárdossy, A. Predicting the regional onset of the rainy season in West Africa. Int. J. Climatol. 2008, 28, 329-342.

4. Laube, W.; Schraven, B.; Awo, M. Smallholder adaptation to climate change: Dynamics and limits in Northern Ghana. Clim. Chang. 2009, 111, 753-774.

5. Farauta, B.K.; Egbule, C.L.; Idrisa, Y.L.; Agu, V.C. Farmers' Perceptions of Climate Change and Adaptation Strategies in Northern Nigeria: An Empirical Assessment. Available online: http://www.atpsnet.org/Files/rps15.pdf (accessed on 15 May 2015).

6. Adger, W.N.; Huq, S.; Brown, K.; Conway, D.; Hulme, M. Adaptation to Climate Change in the Developing World. Available online: http:/www.glerl.noaa.gov/seagrant/ClimateChangeWhiteboard/ Resources/Uncertainty/climatech/adger03PR.pdf (accessed on 9 May 2015).

7. Intergovernmental Panel on Climate Change (IPCC). Climate Change 2001: Impacts, Adaptation, and Vulnerability. Intergovernmental Panel on Climate Change; Cambridge University Press: Cambridge, UK, 2001. 
8. Fosu-Mensah, B.Y.; Vlek, P.L.G.; MacCarthy, D.S. Farmers' perceptions and adaptation to climate change: A case study of Sekyeredumase district in Ghana. Environ. Dev. Sustain. 2012, 14, 495-505.

9. Nhamo, N.; Daniel, M.; Fritz, O.T. Adaptation strategies to climate extremes among smallholder farmers: A case of cropping practices in the Volta Region of Ghana. Br. J. Appl. Sci. Technol. 2014, 4, 198-213.

10. Okonya, J.S.; Syndikus, K.; Kroschel, J. Farmers' perceptions of and copping strategies to climate change: Evidence from six agro-ecological zones of Uganda. J. Agric. Sci. 2013, 5, doi:10.5539/jas.v5n8p252.

11. Apata, T.G. Factors Influencing the Perception and Choice of Adaptation Measures to Climate Change among Farmers in Nigeria. Evidence From farm Households in Southwest Nigeria. Available online: http://businessperspectives.org/journals_free/ee/2011/ee_2011_04_Apata.pdf (accessed on 9 May 2015).

12. Nhemachena, C.; Hassan, R. Micro-Level Analysis of Farmers' Adaptation to Climate Change in Southern Africa. Available online: http://cdm15738.contentdm.oclc.org/utils/getfile/collection/ p15738coll2/id/39726/filename/39727.pdf (accessed on 23 May 2015).

13. Kusakari, Y.; Asubonteng, K.O.; Jasaw, G.S.; Dayour, F.; Dzivenu, T.; Lolig, V.; Donkoh, S.A.; Obeng, F.K.; Gandaa, B.; Kranjac-Berisavljevic, G. Farmer-perceived effects of climate change on livelihoods in Wa West District, Upper West Region of Ghana. J. Disaster Res. 2014, 9, 516-528.

14. Lindsay, P.H.; Norman, D.A. Human Information Processing: An Introduction to Psychology. Available online: http://www.phon.ucl.ac.uk/courses/spsci/audper/SDT\%20Lindsay\%20\&\%20Norman \%20App\%20B.pdf (accessed on 4 August 2015).

15. Harig, T.; Kaiser, F.G.; Bowler, P.A. Psychological restoration in nature as a positive motivation for ecological behavior. Environ. Behav. 2001, 33, 590-607.

16. Ministry of Environment, Science and Technology (MEST) of Ghana. Ghana Goes for Green Growth: National Engagement on Climate Change. Available online: http://prod-http-80-800498448.us-east1.elb.amazonaws.com/w/images/2/29/GhanaGreen.pdf (accessed on 4 August 2015).

17. Luni, P.; Maharjan, K.L.; Joshi, N.P. Perceptions and realities of climate change among the Chepong Communities in rural mid-hills of Nepal. J. Contemp. India Stud. Space Soc. 2012, 2, 35-50.

18. Di Falco, S.; Yesuf, M.; Kohlin, G.; Ringler, C. Estimating the impact of climate change on agriculture in low-income countries: Household level evidence from the Nile Basin, Ethiopia. Environ. Resour. Econ. 2012, 52, 457-478.

19. Jackson, L.E.; Pascual, U.; Hodgkin, T. Utilizing and conserving agrobiodiversity in agricultural landscapes. Agric. Ecosyst. Environ. 2007, 121, 196-210.

20. Ndamani, F.; Watanabe, T. Influences of rainfall on crop production and suggestions for adaptation. Int. J. Agric. Sci. 2015, 5, 367-374.

21. Ghana Statistical Service (GSS). Population by Region, District, Locality of Residence, Age Groups and Sex, 2010. Available online: http://www.statsghana.gov.gh/docfiles/population_by_region_ district_locality_of_residence_age_groups_and_sex,_2010.pdf (accessed on 15 May 2015).

22. Uddin, M.N.; Bokelmann, W.; Entsminger, J.S. Factors affecting farmers' adaptation strategies to environmental degradation and climate change effects: A farm level study in Bangladesh. Climate 2014, 2, 223-241.

23. Devkota, R.P.; Cockfield, G.; Maraseni, T.N. Perceived community-based flood adaptation strategies under climate change in Nepal. Int. J. Glob. Warm. 2014, 6, 113-124. 
24. Mertz, O.; Mbow, C.; Reenberg, A.; Diouf, A. Farmers' perceptions of climate change and agricultural adaptation strategies in rural Sahel. Environ. Manag. 2009, 43, 804-816.

25. Intergovernmental Panel on Climate Change (IPCC). Contribution of Working Group II to the Fourth Assessment Report of the Intergovernmental Panel on Climate Change, 2007; Parry, M.L., Canziani, O.F., Palutik, J.P., Linden, P.J. Hanson, C.E., Eds.; Cambridge University Press: Cambridge, UK, 2007.

26. Kandlinkar, M.; Risbey, J. Agricultural impacts of climate change: If adaptation is the answer, what is the question? Clim. Chang. 2000, 45, 529-539.

(C) 2015 by the authors; licensee MDPI, Basel, Switzerland. This article is an open access article distributed under the terms and conditions of the Creative Commons Attribution license (http://creativecommons.org/licenses/by/4.0/). 